\title{
Calități esențiale ale preotului și ale monahului pentru o misiune rodnică
}

\section{Ștefan-Gabriel CARAȘ}

\begin{abstract}
Within the parish or the monastery, both the priest and the monk, are required to have certain qualities both interior and exterior. I have highlighted in this study, several of these qualities, some being specific to the priest, and others to the monk, even though their mission is the same. Purely human qualities, necessary to any person, followed by the special qualities, necessary to the priest, like the culture, the spirituality, the ecumenism, the knowledge of oneself, of daily realities, his relations with the laity, are highlighted here, briefly. Also, I have shown some qualities specific to the monk, who by his role in the world but also outside the world, can and must have an important role in the life of the believers. At the end, I showed that, both the church and the monastery need each other, in their mission, the sanctification of the human being easier to reach when the two doors to heaven collaborate, their relationship being a perichoretic one, of interpenetration and not separation.
\end{abstract}

Keywords: culture, spirituality, parish, monastery, sanctification. 
Într-o lume care se pare că tinde spre desacralizare, în care Dumnezeu este lăsat la o parte și la care se apelează de către cei mai mulți doar în momentele importante ale vieții (Botez, Cununie, Înmormântare, plus anumite sărbători mari) sau nici măcar atunci, Biserica prin slujitorii ei, preoți şi monahi, are datoria sacră, aceștia fiind investiți cu putere sacramentală, să resfințească acest pământ împreună cu oamenii locuitori ai săi și să îi apropie de Dumnezeu. Însă pentru aceasta este necesar ca această ,sare a pământului” (Matei 5,13) să fie înmiresmată de anumite calități, competențe, altfel riscăm să cădem în derizoriu, să ajungem să fim doar nişte prestatori de servicii şi atât, iar rolul Bisericii în societate să treacă pe un loc nesemnificativ. Sfântul Apostol Pavel enumeră câteva calități ale preotului (I Timotei 3,1-13). Noi ne vom rezuma doar la câteva calități ale preotului de mir în prima parte a lucrării, iar în a doua parte la câteva calități ale monahului.

\section{Preotul de mir astăzi și câteva calități pe care trebuie să le aibă acesta pentru a face 0 misiune rodnică}

\subsection{Curățenia interioară, căpetenia celorlalte calități misionare ale preotului}

În primul rând, preotul trebuie să știe că pentru a-i putea apropia pe ceilalți de Dumnezeu, pentru a fi un bun misionar, trebuie să aibă grijă ca el însuși să fie curat, vindecat de patimi. Iisus Hristos spune: ,,Doctore, vindecă-te pe tine insuți!!” (Luca 4, 23), iar Sfântul Antonie cel Mare tot în acest ton afirmă: ,Ai grijă de tine însuți și de sufletul tău". De asemenea Sfântul Grigorie de Nazianz spune:

\footnotetext{
1 ***Patericul, Antonie 1, PG 65, 76, apud Emilianos, Timiadis, Preot, parohie, innoire: noțiuni și orientări pentru teologia și practica pastorală, trad. Paul Brusanowski, București, Edit. Sophia, 2001, p. 8.
} 
„, Trebuie să fiu eu mai întâi curat și apoi să curăț pe alții. Să fiu eu ințelept, ca să înțelepțesc pe alții. Să fiu eu luminăa, ca să luminez pe alții. Să fiu eu aproape de Dumnezeu, ca să apropii pe alții. Să fiu eu sfânt, ca să sfințesc pe alții"’. $\mathrm{Cu}$ alte cuvinte, nu poate preotul prins în plasa patimilor să fie un reper moral pentru cei din jurul său, într-o lume în care omul postmodern depărtat de Dumnezeu, atunci când caută sacrul, de multe ori separă preotul de Dumnezeu, chiar Biserica în sine de Dumnezeu. Este o realitate pe care o constatăm, omul crede în Dumnezeu, dar nu mai crede în Biserică și implicit în slujitorii ei, preoții. Sfântul Ioan Gură de Aur spune: „, Să fie puși în această slujbă înaltă numai bărbații aceia care întrec cu mult pe toți ceilalți oameni, în virtutea sufletului"'s. Dacă preotul este preot doar în biserică, iar în afara ei se comportă ca și un laic, mesajul acestuia rostit din amvon va fi un mesaj lipsit de conținut, unul gol. Astfel, perfecționarea, identificarea cu adevărul a propriei persoane, este esențială pentru orice preot. Pentru a putea face misiune, o bună misiune, este imperios necesar să fim hristofori, asemenea lui Pavel (Galateni 2, 20). Dumnezeu Însuși, prin exponentul Său uman, cea de a doua Persoană din Treime, Iisus Hristos, exemplul absolut, suprem de misionar, ne cheamă la sfințenie (Levitic 11, 45; 19, 2). Nici nu este posibil altfel, nu poți aduce un plus în comuniunea cu ceilalți, nu poți fi exemplu, dacă tu însuți nu ești un exemplu pentru propria conștiință, pentru propriul eu. Practic putem spune că misiunea, calitatea acesteia depind fără doar și poate de calitatea celui ce face misiunea, a misionarului. Cum să înveți tu pe altul dacă nu ești tu însuți învățat, cum să apropii pe ceilalți de adevăr dacă tu însuți nu cunoști adevărul, cum să sfințești pe cineva dacă tu însuţi ești departe de sfințenie. Însuși Iisus Hristos spune răspicat și fără echivoc: ,,Omul

\footnotetext{
${ }^{2}$ Sfântul Ioan Gură de Aur, Sf. Grigorie de Nazianz, Sf. Efrem Sirul, Despre Preoție, trad., introd. și note de Dumitru Fecioru, București, Edit. Sophia; Biserica Ortodoxă, 2004, p. 265.

${ }^{3}$ Ibidem, p. 55.
} 
bun, din vistieria cea bună a inimii sale, scoate cele bune, pe când omul rău, din vistieria cea rea a inimii lui, scoate cele rele. Căci din prisosul inimii grăieşte gura lui" (Luca 6,45). Astfel, constatăm că prima calitate a preotului este calitatea propriei persoane.

\subsection{Preotul să fie deschis spre cei de alte confesiuni religioase, să cunoască învățătura teologică a acestora}

Preotul de mir nu poate să fie străin de cultura vremurilor în care trăiește, atât cea teologică cât și cea laică, să fie un om care discerne adevărul de neadevăr, falsul de autentic, deschis la ceea ce este bun chiar dacă acest bun îl găsește în învăţătura altor credințe decât cea ortodoxă, pentru că Sfântul Pavel spune ,, Toate să le încercaţi; țineţi ce este bine" (1 Tesaloniceni 5, 21), cel ce a fost cel mai bine informat dintre apostoli. Noi știm și afirmăm că Biserica Ortodoxă deține Adevărul, dar în același timp recunoaștem că adevăr, într-o măsură mai mică sau mai mare, există și la alte confesiuni religioase, adevăr care trebuie extras și mărturisit de către preot. Diplomaţia față de celelalte confesiuni, mai ales acolo unde ele există chiar în aceeași comunitate, sat sau oraş, este importantă, însă fără ca această diplomație să devină o relativizare o propriei credințe, ci pur și simplu să vezi partea bună a celui de lângă tine. Punctualitatea la slujbe a protestanților, programele numeroase cu tinerii ale romano-catolicilor, pot fi anumite exemple pe care le putem prelua de la aceștia. Sau în diaspora, generozitatea cu care își oferă romano-catolicii bisericile ca și spații de slujire pentru preoții ortodocşi care nu au unde sluji, este un alt exemplu la care trebuie să reflectăm. Această deschidere este absolut necesar să fie reciprocă pentru o misionarizare rodnică, iar actualul Papă, Francisc I, cel puțin la nivel vizibil, pare să fie foarte deschis, credincioșii receptând aceasta pozitiv. În acest context criticarea credinței celor de altă confesiune, dărâmarea credinței lor, ar trebui înlocuite cu promovarea credinței ortodoxe autentice, fără repulsie sau chiar răutate 
față de ceilalți, neortodocșii, care până la urmă sunt și ei chemați de Dumnezeu (Matei 26, 16). Binențeles că Iisus Hristos a spus clar „Pe această piatră voi zidi Biserica Mea" (Matei 16, 18), ceea ce arată că există doar o singură Biserică adevărată, pentru că nu pot exista două adevăruri, iar acest adevăr îl deținem, dar nu putem afirma că doar noi deținem tot adevărul, iar alții nu îl dețin deloc, sau că numai și numai cei ortodocși au acces la mântuire. Dacă ar fi așa, ar însemna că majoritatea covârșitoare a oamenilor nu se mântuiesc, pentru că cei ortodocși sunt puțini. În acest sens, a afirma că doar acea mică parte din omenire, doar cei ortodocși se pot mântui ar însemna că Dumnezeu a fost înfrânt de diavol. Cu atât mai mult cu cât și din cei botezați în credința ortodoxă, doar o parte sunt practicanți, și din păcate o parte mică. Astfel, preotul trebuie să dețină calitatea de mărturisitor al adevărului și să afirme clar, că nu ajunge să fii ortodox pentru a te mântui. E ca și cum un copil se înscrie la școală în clasa pregătitoare. Are dreptul din acest moment să primească premiu, să fie olimpic, să termine școala, dar să nu uităm un lucru, are doar dreptul și atât, însă nu i se cuvin din oficiu. Așa și cu credincioșii ortodocși, pot deveni sfinți, dar pot rămâne și repetenți, să fie excluși de la masă (Matei $21,43 ; 22,13)$. Deci preotul trebuie să mărturisească fără echivoc că omul îl poate primi sau cunoaşte pe Hristos cel mai bine în cadrul Bisericii Ortodoxe, cea care are instrumentele necesare care îl duc pe om la mântuire, dar în același timp să nu credem că toți ceilalți, cei neortodocşi nu au nicio șansă la mântuire. Afirmația scolastică a Sfântului Ciprian al Cartaginei „Extra Ecclesiam nulla sallus", $\mathrm{nu}$ făcea referire la Biserica Ortodoxă, pentru ca acesta a trăit în secolul trei creștin (200-258).

${ }^{4}$ Isidor Todoran, Ioan Zăgrean, Dogmatica ortodoxă: manual pentru seminariile teologice, Ed. a 9-a, Cluj-Napoca, Edit. Renașterea, 2009, p. 246. 


\subsection{Preotul să fie la curent cu cele mai proaspete informații și} să ajute la construirea în gândirea credincioșilor a unui Dumnezeu autentic

Nu ajunge ca preotul să fie un bun teolog și să fie curat sufletește, ci trebuie să cunoască ceea ce se întâmplă în lume, în jurul lui practic. Preotul fiind o persoană comunitară în mod natural ia contact cu oamenii, credincioși sau nu. Nu poate lega punți cu aceștia dacă nu cunoaște și altceva în afară de teologie. Devine aproape plictisitor un om care vorbește doar pe un anumit palier, mai ales în societatea actuală. Este o necesitate obligatorie ca preotul să cunoască situația lumii în care trăiește, altfel cade în derizoriu. Oamenii chiar au pretenția ca preoții să fie bine informați, în acest sens exprimânduse un parlamentar al României, din anii 90: „Domnilor Parlamentari, despre problemele acestea importante ce le discutăm să nu-i întrebăm numai pe intelectuali, ci și pe ofițeri și pe preoți"’. Însuși Ioan Botezătorul era informat de ceea se întâmpla în acea vreme, pentru că îl vedem vorbind cu Irod, cu soldații, cu fariseii, și vorbea cu fiecare pe limba lui (Luca 3, 10-19). Mesajul era unul de pocăință, de îndreptare, dar nu unul generalizat, ci vorbea în funcție de persoană. Astăzi constatăm că preotul secolului 21 este bine informat, având și mijloacele necesare la îndemână, dar ceea ce este important în misiunea acestuia, constă în capacitatea de a putea înțelege, că ceea ce se întâmplă în societate, la nivel politic, medical etc, nu este neapărat în contradicție cu misiunea Bisericii, dimpotrivă, provocările actuale, deschid noi orizonturi de misiune pentru aceasta, în același timp întărindu-o. Dăm ca și exemplu problema predării religiei în școlile din România, după reglementările Curții Constituționale.

Pe de altă parte, preotul este necesar să dețină calitatea de apărător al credinței autentice chiar și în fața afirmațiilor colegilor săi, clerici. Să aibă calitatea de mărturisitor al adevărului, așa cum

${ }^{5}$ Ibidem. 
la primul Sinod Ecumenic (Niceea, anul 325), chiar un membru al Bisericii, preotul Arie a fost condamnat pentru afirmațiile sale.

Preotul trebuie să aibă dreaptă socoteală și să le imprime această stare și credincioșilor. Să elimine din gândirea lor ideea unui Dumnezeu capricios, imprevizibil, arbitrat ${ }^{6}$, care îi fac pe oameni nu robi ci sclavi ai lui Dumnezeu. O problemă reală este faptul că oamenii ajung de fapt să fie dependenți de unii preoți, care din anumite motive, promovează acest tip de comportament, acest tip de relație preot-credincios, credincios-Dumnezeu. Se poate întâmpla ca acest comportament să aibă efecte negative asupra credinciosului chiar la nivelul societății, problema cardului de sănătate fiind grăitoare de la sine.

Binențeles că, în același timp, preotul misionar trebuie să întărească și să susțină adevărurile afirmate de către alți clerici, chiar dacă devine astfel un opozant al mentalității laice, sau chiar al libertății de exprimare, de gândire, atât de mult susținute în ultima vreme. Dăm ca exemplu parteneriatul între persoanele de același sex, idee tot mai pregnantă în societatea românească, care este în totală contradicție cu învățătura divină.

\section{Educația preotului, un aspect misionar vital}

În acelaşi timp, observăm că un misionar trebuie să fie bine educat altfel este ineficient și chiar dăunător, distrugător, după cum spune Hristos: „Poate orb pe orb să călăuzească? Nu vor cădea amândoi în groapă? " (Luca 6, 39). Pentru a conduce pe cineva spre veșnicie, trebuie ca preotul, pentru a deveni unul bun, să Îl cunoască pe Dumnezeu, pentru că Hristos a spus: ,Aceasta este viața veșnică Să Te cunoască pe Tine, singurul adevăratul Dumnezeu" (Ioan 17,

\footnotetext{
${ }^{6}$ Teofil Tia, ,Doctore, vindecă-te pe tine însuți” - Exigențele autoterapiei psihopastorale, Alba-Iulia, Edit. Reîntregirea, 2003, p. 6.
} 
3). Pe de altă parte, o pregătire slabă teologică, o preoție bazată doar pe tradiții și cutume, dar fără argumente clare teologice, îl transforma pe preot într-o ,călăuză oarbă ” (Matei 23, 16), aceștia mai putând fi numiți și ,nebuni și orbi” (Matei 23, 17, 19). Poetul latin Publius Syrus (85 î. Hr. - 43 d. Hr.) spunea astfel: „, Trist ajutor e acela care, In timp ce sprijină, Vatămă! "’. Tot în acest sens filosoful grec Socrate spunea: „Cei care știu ce este fiecare lucru, sunt în stare să explice și celorlalți; pe când cei care nu știu e firesc să se înșele și pe ei și să inșele și pe alții" ". Iisus Hristos s-a dat pe Sine exemplu (Matei 11, 29), iar aceasta calitate de învățător a transferat-o asupra ucenicilor Săi, asupra preoților (Matei 28, 19).

Putem vorbi aici de credința gândită, credință afirmată în scrierile lui Clement Alexandrinul care ,se silește să le demonstreze creștinilor din timpul său că a-ți gândi credința, a ți-o întemeia și dialectic, nu numai prin trăire, nu este nici primejdios și nici inutil”". În altă ordine de idei Sfântul Grigorie de Nyssa consideră educaţia preotului cea mai importantă condiție pentru a putea face misiune: „, cei dintâi care trebuie să cunoască adânc învățătura creștină sunt puși să îndrume viața și dreapta credință, pentru ca prin ea Biserica să crească, iar numărul celor intrați în rânduielile ei să se înmulțească prin propovăduirea cuvântului adevăratei credințe" ${ }^{10}$. Pentru a putea învăța trebuie tu însuți să fii învățat altfel nu poți să faci misiune, ci doar contra-misiune, care păgubește în loc să aducă un folos, putând

\section{${ }^{7}$ Ibidem, p. 2.}

${ }^{8}$ Idem, Contra-misiunea preotului prin incultură, Alba-Iulia, Edit. Reîntregirea, 2004, p. 21.

${ }^{9}$ Dumitru Fecioru, Viața lui Clement Alexandrinul, în: Clement Alexandrinul, „Scrieri”, partea întâi, trad. Dumitru Fecioru, col. P.S.B., vol. 4, București, Edit. IBMBOR, 1982, p. 5, apud Dorin Opriș, Dimensiuni creștine ale pedagogiei moderne, Ed. a 3-a, București, Edit. Didactică și Pedagogică, 2012, p. 155.

${ }^{10}$ Sfântul Grigorie de Nyssa, Marele cuvânt catehetic, în ,Scrieri”, trad. Grigorie Teodorescu, partea a doua, București, Edit. Sophia, 1998, p. 286, apud, Dorin Opriș, op. cit., p. 172. 
vorbi aici despre „,contra-misiunea preotului prin incultură ${ }^{\prime \prime 11}$.

Intr-un cuvânt preotul învăţător trebuie să fie un exemplu pentru cei pe care îl ascultă: , Și după cum omul, oriunde s-ar arăta, trebuie să se vadă că se deosebește de animale, tot așa și învățătorul trebuie să arate că este invățător și când grăiește, și când tace, și când stă la masă, și când face altceva; trebuie să se vadă că este invățător și din mers, și din privire, și din ținută, într-un cuvânt din toate” ${ }^{12}$.

\section{Cele trei voturi monahale, calități esențiale ale monahului}

Dacă anumite mănăstiri sunt bogate, și nu este nimic rău în aceasta, nu putem concepe ca și călugării să fie bogați. Renunțarea la lume înseamnă renunțarea la tot ceea ce presupune lumea, printre care și bogația. În cadrul mănăstirii, călugărul își pune la dispoziția starețului bunurile proprii care devin astfel bunuri ale obștii întregi, practic călugărul nu mai are nimic personal. Însă această sărăcie de bună voie nu trebuie să ajungă la extrem, chiar dacă avem exemple de călugări care dormeau pe o scândură, mâncau o dată pe zi, sau aveau hainele rupte. Aceștia sunt excepții care au rolul lor în lume, exemple de sfințenie, dar aici vorbim de călugărul comun. Lumea caută astăzi călugări care să le fie călăuză, exemple de modestie și de sfințenie, pentru care bunurile materiale sunt neimportante, într-o lume care gonește după avere. Acești călugări pot face o misiune rodnică în rândul pelerinilor pe de o parte, iar în alt sens, strict personal, dezlipirea de bogății le aduce acestora liniștea interioară izvorâtă din conștiința că își îndeplinesc votul depus, cât și din conștiința că, mergând pe acest drum asumat, vor dobândi bunătățile cele veșnice,

${ }^{11}$ Teofil Tia, Contra-misiunea preotului prin incultură, Alba-Iulia, Edit. Reîntregirea, 2004, p. 3.

${ }^{12}$ Sfântul Ioan Gură de Aur, Omilii la Matei, în „Scrieri”, trad. Dumitru Fecioru, partea a treia, colectia P.S.B., vol. 23, București, Edit. IBMBOR, 1994, p. 823, apud Dorin Opriș, op. cit., p. 178. 
incomparabile cu toate bogăţiile lumii acesteia (Matei 6, 19-21). La polul opus găsim și monahi care își etalează bogația proprie, monahi care stârnesc nemulțumire în rândul credincioșilor, chiar smintindu-i pe aceștia, acest tip de monahi depărtându-se de chemarea lor, în acelaşi timp depărtându-i și pe pelerini de ei. Acești monahi părăsesc frecvent spaţiul sacru al mănăstirii, încercând să guste din provocările lumii. Hainele și accesoriile scumpe sunt câteva din semnele unui monah nu înduhovnicit, ci îndestulat din punct de vedere material. Însă, chiar dacă nu își etalează bogățiile în afara mănăstirii, astfel smintind pe alții, monahul poate trăi chiar și în cadrul mănăstirii într-o stare bună materială, ceea ce îl face să-și încalce propriul vot, astfel ratându-și misiunea. Legat de monahii care nu s-au dezlipit de cele materiale citim în Pateric: „Un frate, care s-a lepădat de lume și a împărțit averile sale săracilor, ținând puține pentru sine, a mers la avva Antonie. Și despre acestea cercetându-l bătrânul cu de-amănuntul, $i$-a zis: "De voiești să te faci monah, mergi în satul cutare, cumpără carne, și pune-o împrejurul trupului tău gol și apoi vino aici». Și făcând fratele așa, câinii și păsările îi rupeau (sfâșiau) trupul. Și, ajungând el la bătrânul, acesta îl întreba de a făcut cum l-a sfătuit. Iar acela, arătându-i trupul lui sfâșiat, sfântul Antonie i-a zis: "Cei ce se leapădă de lume și voiesc să aibă bani, astfel sunt sfâșiați de dracii care-i luptă»" "13.

Însă votul sărăciei de bună voie este valabil și în cazul preotului de mir, sau în rândul mirenilor, nu la nivelul unui călugăr care este dezlipit de lume și de pretențiile ei într-un grad înalt, dar oricum toți suntem chemați să răspundem chemării lui Hristos (Matei 6, 33).

În privința castității, din moment ce călugărul este o persoană celibatară, este o consecinţă firească să-și păstreze castitatea, acesta dedicându-şi întreaga viaţă lui Dumnezeu. Binențeles că și aici observăm că această calitate este valabilă și în cazul preotului sau al mireanului, în sensul că și aceștia se păstrează din acest punct

13***, Pateric, Ed. a 4-a, Alba-Iulia, Edit. Reîntregirea, 2004, pp. 7-8. 
de vedere doar soțului sau soției, împreună formând un singur trup (Efeseni 5,31). Călugărul spre deosebire de mirean, nu lucrează extensiv în sensul de procreere, misiunea lui fiind în principal una interioară, de sfințire a propriei persoane, fiind dedicat într-u totul Bisericii lui Hristos. O latură importantă a căsătoriei este nașterea de copii, această latură în cazul monahului fiind aceea de a naște ucenici, viitori misionari, închinați Miresei lui Hristos, Biserica.

Călugărul trăiește în deplină ascultare de stareț, renuntând la voința proprie, fiind conștient că face voia lui Dumnezeu atât timp cât îl ascultă pe stareț. Această stare de ascultare pe lângă faptul că arată supunere, smerenie, mai arată că monahii trăiesc disciplinat, ordonat, nu fără o rânduială, demonstrând prin fapte că părăsirea lumii cu toate regulile ei stricte, nu înseamnă nicidecum că trăiesc în haos, fără niciun conducător, ci dimpotrivă sunt în deplină ascultare pentru ,c $c \breve{a}$ Dumnezeu nu este al neorânduielii" (1 Corinteni 14, 33). Din nou observăm că această stare de ascultare o găsim și în lume, atât la preot cât și la mirean. Preotul ascultă de autoritatea ierarhică, fără de care nu poate funcționa, depunând chiar un legământ la hirotonie în acest sens, iar mireanul de asemenea nu poate trăi fără să se consulte, fără să asculte de unul sau de altul, fie la locul de muncă, fie în familie, dar şi de duhovnicul propriu, absolut necesar pentru fiecare persoană de pe fața pământului. În privința ascultării, un proverb spune așa: , $\mathrm{Cel}$ ce face intotdeauna ceea ce vrea, arareori face ceea ce trebuie" 14 , sau altul spune astfel: „Cine nu vrea să asculte sfaturile nimănui va învăța pe seama lui" (Celui qui no veut ecouter les conseils de personne s'instruira a ses depens) ${ }^{15}$, scoțând în evidență clar, că omul are nevoie de sfătuire, ascultare de altul pentru a lua decizii bune chiar şi în lume, deci cu atât mai mult în mănăstire, monahul, are chiar

${ }^{14}$ Găsim acest proverb pe coperta de la început în lucrarea părintelui Teofil Tia, Un (im)posibil Diagnostic duhovnicesc al erei post-moderne, Alba-Iulia, Edit. Reîntregirea, 2005.

${ }^{15}$ Idem, Consiliere pastorală și logoterapie, Alba-Iulia, Edit. Reîntregirea, 2012, p. 2. 
obligația sacră de a-1 asculta întru totul pe starețul său.

\section{O scurtă concluzie}

Constatăm că mântuirea credincioșilor, adică a majorității covârșitoare, depinde într-o oarecare măsură de calitatea umană, de calitatea duhovnicească a sacerdotului, cele două calități fiind inseparabile. Dacă acești oameni hirotoniți nu sunt ei înșiși sfințiţi la modul cel mai autentic, dacă aceștia nu se ridică la un nivel duhovnicesc încât să putem spune că într-adevăr sunt ,, sarea pământului”, atunci riscăm să ajungem la drama de a-i conduce nu spre Dumnezeu pe credincioşi ci spre pierzanie.

De aceea considerăm că ceea ce s-a enunţat în acest studiu sunt cîteva calităţi strict necesare pe care trebuie să le dețină atât preotul cât și monahul, toate mergând mână în mână, lipsa uneia dintre ele periclitând întreaga misiune a sacerdotului.

\section{Bibliografie}

1. Biblia sau Sfânta Scriptură, Tipărită sub îndrumarea şi cu purtarea de grijă a Prea Fericitului Părinte Teoctist Patriarhul Bisericii Ortodoxe Române, cu aprobarea Sfântului Sinod, București, Editura Institutului Biblic și de Misiune al Bisericii Ortodoxe Române, 2001.

2. ***, Pateric, Ed. a 4-a, Alba-Iulia, Edit. Reîntregirea, 2004.

3. Bădiliță, Cristian, Sacru și melancolie, Timișoara, Editura Amarcord, 1997.

4. Himcinschi, Mihai, Biserica în societate. Aspecte misionare ale Bisericii în societatea actuală, Alba-Iulia, Edit. Reîntregirea, 2006.

5. Opriș, Dorin, Dimensiuni creștine ale pedagogiei moderne, Ed. a 
3-a, București, Edit. Didactică și Pedagogică, 2012.

6. Tia, Teofil, „Doctore, vindecă-te pe tine insuți”-Exigențele autoterapiei psiho-pastorale, Alba-Iulia, Edit. Reîntregirea, 2003.

7. Idem, Consiliere pastorală și logoterapie, Alba-Iulia, Edit. Reîntregirea, 2012.

8. Idem, Contra-misiunea preotului prin incultură, Alba-Iulia, Edit. Reîntregirea, 2004.

9. Idem, Un (im)posibil Diagnostic duhovnicesc al erei postmoderne, Alba-Iulia, Edit. Reîntregirea, 2005.

10. Saharov, Sofronie, Vom vedea pe Dumnezeu precum este, București, Edit. Sophia, 2005.

11. Semen, Petre, Arheologia biblică în actualitate, Iași, Editura Trinitas, 2008.

12. Sfântul Ioan Gură de Aur, Despre preoție, trad., introd. și note de Dumitru Fecioru, București, Edit. Sophia; Biserica Ortodoxă, 2004.

13. Steinhardt, Nicolae, Dăruind vei dobândi: cuvinte de credință, Rohia, Edit. Mănăstirii Rohia, 2006.

14. Timiadis, Emilianos, Preot, parohie, înnoire: noțiuni și orientări pentru teologia și practica pastorală, trad. de Paul Brusanowski, București, Edit. Sophia, 2001.

15. Todoran, Isidor, Zăgrean, Ioan, Dogmatica ortodoxă: manual pentru seminariile teologice, Ed. a 9-a, Cluj-Napoca, Edit. Renașterea, 2009. 